\title{
COVID-19 prevention and management: Potential applications of humic substances
}

\author{
Diksha Koul ${ }^{1,2}$, Jasmine K. Khosla1, Ravi S. Manhas ${ }^{1,2}$, Devtulya Chander ${ }^{1,2}$ and Asha Chaubey ${ }^{1,2 *}$ \\ ${ }^{1}$ Fermentation Technology Division, CSIR-Indian Institute of Integrative Medicine, Canal Road, Jammu, India \\ ${ }^{2}$ Academy of Scientific and Innovative Research, CSIR-Human Resource Development Centre, Campus Ghaziabad, Uttar Pradesh, India
}

\section{KEY WORDS}

Coronavirus disease

SARS-CoV-2

COVID-19

Humic substances

Shilajit

*Corresponding Author:

Asha Chaubey, PhD

Academy of Scientific and Innovative

Research, CSIR-Human Resource

Development Centre, Campus Ghaziabad,

Uttar Pradesh, India

Contact no: +91-9419211040

E-mail: achaubey@iiim.ac.in

\begin{abstract}
Background: COVID-19 pandemic has forced the human population to rethink over the lifestyle and food habits being followed by them. During the current scenario, when cases of more virulent new strain are emerging and specific treatment are still underway, we must look back to the Darvin's theory of "Survival of the fittest" and in order to sustain the pandemic, we must follow the rule "Prevention is better than cure". Traditional Medicinal System can bring possible solution including prevention and control of COVID-19. Humic substances have been used for antiviral activities, signifying that it has potential applications in the management and prevention of infectious diseases.

Summary: Present article is focused on the assessment of the naturally occurring humic substances, which are major constituents of Shilajit, being used in traditional system of medicine and can be used against for the prevention of COVID-19.

Key message: Humic substances not only improve the immune system, but also have anti-inflammatory, antioxidant and antiviral activities against human RNA viruses. Therefore, while the entire world is preparing to deal with alarming threat of community spread of COVID-19, Humic substances may play a vital role in improving the innate immunity for prevention and management of SARS-CoV-2 infection
\end{abstract}

doi: 10.38205/imcr.020261

\section{Introduction}

Currently, the novel Coronavirus disease 2019 (COVID-19) caused by SARS-CoV-2 has posed a significant threat to global health $(1,2)$. Patients suffering from chronic medical conditions such as lung disease, heart disease, diabetes, chronic kidney disease, severe obesity or liver disease are at high risk of SARS-CoV-2 infection. Till now SARS-CoV-2 has caused millions of infections globally and the death toll has crossed the figure of billions (3). However, older people or those having compromised immune system are always at higher risk (4), although the young generation is not invulnerable and suffered during the second wave. Recent interventional trials suggest that populations at high risk may adopt the Indian traditional system of medicine. This system aims to focus on prevention through dietary management, lifestyle modification and preventive measures for improving immunity (5-7).

Despite the availability of vaccines, we have a long way to go to make them available globally. Thus, traditional medicine plays an important role, not only in mitigation of COVID-19 but also for other infections that might come in future. In this context, reconsidering Traditional Medicinal System can bring possible solutions including prevention and control of COVID-19 (8). COVID-19 has shown a direct association with adaptive and innate immune responses.
Traditional medicines play an important role in boosting immune responses against such pathogenic invasions and the fight against viral infections can be dealt with in a better way with good immunity (9).

The humic acid substances are various naturally occurring substances that are formed after decomposition of rocks and minerals into the upper layer of soil called humus. These are primarily humic acid, fulvic acid, minerals and some organic compounds. Shilajit is one such traditional formulation used in India for centuries, made up of humic substances and is used as a rejuvenator and anti-ageing medicine (10).

Humic substances and shilajit, are known to control antiviral activity, different components of humic substances are active against viral infections like human immunodeficiency virus, herpes simplex virus, influenza virus etc (11).

Here, we summarise the role of humic substances, which have been used since centuries for the treatment and prevention of diseases associated with inflammation.

\section{Shilajit and Humic substances}

Shilajit, also known as Salajit, Silajatu, Mimie, or Mummiyo in the north of India, is a brown to blackish powder from high mountain rocks. These rocks are especially located in the Himalayan Mountains between India and Nepal (10). 
For centuries, it is known as an anti-ageing and rejuvenator compound in Ayurvedic medicine which is used to increase physical strength and boost human health in ancient Indian Ayurvedic medicine (12). Humic substances are the major components of Shilajit, which are formed by heteropoly condensation of carbohydrates, proteins, fatty acids, lignins, tannins and many other materials depending on their origin (13). The paramount sources of organic components of humic substances are water and soil (14).

The constituents of Shilajit include four primary chemical units i.e. (i) Selenium (selenoproteins or enzymes i.e. selenocysteine and seleno-methionine) (ii) Non-humic organic compounds comprising of conjugated and free derivatives (e.g. lipoidal, aminoacyl, fattyacyl), dibenzo-pyrones (iii) DCPs (dibenzo-pyrones-chromoproteins) and (iv) metallo-humates like fulvic acids (15). Various important components of Shilajit have been depicted in Fig. 1.

\section{Sources of Humic substances}

Humic substances are mostly present in marine, river water and soil etc. According to their source of origin, they differ in their characteristics. E.g. humic substances in streams are different to those from soils or the ocean. Aquatic humic substances account for almost 30 to $50 \%$ of the organic carbon in water (16). Marine humic substances have some specific aromatic character and are distinct from stream and soil humic substances. Various algal sources of fulvic acid have been derived from ponds and lakes (17). Algal derived fulvic acids are indeed yellow but same as terrestrially derived fulvic acids. Different sources known to produce humic substances are shown in Table 1.

\section{Properties of Humic Substances}

Fulvic acids are a family of natural organic acids and components of the humus. They are very similar to humic acids, differentiated by oxygen and carbon contents, degree of polymerization, acidity, inter-mediate molecular weight and color (26). Traditionally, fulvic acid is used for brain-related disorders such as Alzheimer's diseases, respiratory tract infections, fatigue, heavy metal toxicity, preventing hypoxia and is well studied for its effect on immune health and reducing inflammation $(27,28)$. It serves as an important vehicle that carries nutrients and vitamins to the exact place in our bodies (29). Traditionally, humic acid is consumed for boosting the immune system for treating the swine flu, avian flu, influenza flu and other viral infections (30).

\section{Nutraceutical applications of Humic substances}

There are many properties of fulvic acid and humic acid which are beneficial to humans, making it a good nutraceutical candidate. Fulvic acid has been described as an important component of nutraceutical beverages (31). The Fulvic acid acts as an electrolyte, balancing the ionic content of the body fluids and may act as an electron acceptor or donor as per the need of the cells. In addition to this, it also forms free complexes with various other ions leading to their increased bioavailability (32). The complexes formed with fulvic acid are low molecular weight complexes. As a result, they can easily pass through the plasma membrane. It is also known to increase the enzyme activity, particularly of respiratory enzymes (33).



Fig. 1 Components of Shilajit (67) 
Table 1: Common sources of Humic acid substances

\begin{tabular}{|c|c|c|c|}
\hline Source & Example & Environment & Reference \\
\hline \multirow[t]{5}{*}{ Algal species } & Chlamydomonas intermedia chodat & Pony lake, feather pond & \multirow[t]{5}{*}{$(17)$} \\
\hline & Chlorococcum sp. & Pony lake & \\
\hline & Cryptomonas sp & Pony lake & \\
\hline & Navicula sp. & Pony lake, feather pond & \\
\hline & Chroococcus sp. & Pony lake, feather pond & \\
\hline Plant source & cellulose, Hemicelluloses, Lignin, Tannins & Soil & $(18,19)$ \\
\hline \multirow[t]{3}{*}{ Fungal isolate } & Cercospora beticola & $\begin{array}{l}\text { leaf spot disease of the sugar beet } \\
\text { (Beta vulgaris L.) }\end{array}$ & $(20)$ \\
\hline & Pisolithus tinctorius & ectomycorrhizal fungus & $(21)$ \\
\hline & Myxotrichum sp. & endolichenic fungus & $(22)$ \\
\hline Natural materials & Shilajit & Rocks, high mountain rocks & $(23)$ \\
\hline Water source & $\begin{array}{l}\text { anion exchange, cation exchange, and molecule- } \\
\text { adsorbing resins. }\end{array}$ & $\begin{array}{l}\text { Jewell pond } \\
\text { Oyster river }\end{array}$ & $(24)$ \\
\hline Soil & $\begin{array}{l}\text { Isolation technique by using a modification of the } \\
\text { method of Schnitzer and Skinner } 1968\end{array}$ & B2 horizon of a Podzol soil & $(25)$ \\
\hline
\end{tabular}

The enzymes influenced by fulvic acid include alkaline phosphates, transaminase, and invertase. Due to its antioxidant nature, it acts as a free radical scavenger for the body. It increases the DNA content within the cell as well as increases the RNA synthesis. It also acts as a catalyst by forming a complex with vitamin and metal ions. Fulvic acid is an organic natural electrolyte and balances the ionic balance in body fluids (31).

In addition to various metabolic enhancing and protecting properties, fulvic acid has been found to be of immense importance in curing various diseases. It has been found to cure cases of dementia (34) and promote disassembly of Tau fibrils (35). Even in the case of diabetes, fulvic acid can increase superoxide dismutase activity in pancreatic beta cells leading to a reduction in hyperglycemia (36). It is also reported that a fulvic acid bath can cure ulcers with a $90 \%$ success rate (37).

Activation of the immune system by fulvic acid to kill bacteria and promotes gut health is well established. It is effective in inhibiting gastroenterological bleeding with a $95.6 \%$ success rate (38). Similar to fulvic acid, humic acid have also been found to cure haemorrhagic fever and prevents cancers of oesophagus with a $100 \%$ success rate, $90 \%$ success rate in case of thyroid cancer, and with same success rate in case of curing ulcers (39). The cytotoxic effect of humic acid on adenocarcinoma has also been reported (40). Humic acid induces the release of plasminogen activators and converts plasminogen into plasmin, which degrades insoluble fibrin to soluble fibrinogen degradation product (41).

In nutshell, humic substances act as a booster of body functions and respiratory enzymes, working as an electrolyte and as a transporter of minerals. The humic substances may also provide a metabolic boost to a person by rejuvenating activity. Humic substances also act as prophylactic against various ailments including cancer, diabetes and other diseases, making them excellent candidates for nutraceutical applications.

\section{Immunomodulatory activity of humic substances}

Many studies indicate that these acids help in reducing the release of proinflammatory mediators from cells (42). It is also shown that fulvic acid and humic acid at $200 \mu \mathrm{g} / \mathrm{mL}$ can lessen tumour necrosis factor alpha expression after an exposure to the endotoxin lipopolysaccharide in differentiated Human monocytes (43). Many studies have discovered a positive response to treatment on humic acid dosage in treating viral respiratory illness (44). Humic substances are biologically active immunomodulators which are affecting both the cellular and humoral branches of immune reactions. (45). A humic substance such as fulvic acid helps in the activation of the immune system so that it can eradicate bacteria, reduces pro-inflammatory markers. The anti-ageing property of humic acid is attributed to its ionic balance maintenance (46). Fulvic acid derived from carbohydrates can stop the succession of the wound infection. Many studies show the role of fulvic acid in macrophages, stimulating immune function and intracellular signalling $(47,48)$.

\section{Shilajit}

The lytic potential of Shilajit was found to produce T-cell mediated cytotoxicity and supplement activated lymphocytes. The shilajit used for treating lymphocytes has the ability to lyse ${ }^{51} \mathrm{Cr}$ labelled tumour cells (49). The immuno-modulatory results in mice that were given by shilajit extract were evaluated. The white blood cell activity was observed before and at intervals after receiving the extract of shilajit or a placebo. The extract of shilajit increased the activity of the white 
blood cells and it was observed that the experimental activity was dose dependant on the time of exposure (50). 25 and $50 \mathrm{mg} / \mathrm{kg}$ dose of shilajit for 5 days remarkably lowered the level of 5-hydroxy tryptamine, 5-hydroxy indole acetic acid, resulting in an increase in noradrenaline, dopamine level and its metabolites in the brain of rats. Such modifications in levels of neurotransmitters were found to be similar to those having increased humoural activity (10). Shilajit has been proven to provide immuno-potentiating properties, which improves the immunity that may complement conventional therapy in HIV. Compound formulation having pure shilajit as one of the most important constituents gained marked progress in the augmentation and symptoms in counts of CD4 and CD8 cells in clinical research studies of patients with HIV.

\section{Selenium}

Selenium is a key trace element involved in several crucial metabolic activities via enzymes or selenoproteins that are vital in providing protection against oxidative damage and thus helps to regulate immune function. It has also been established that an adequate quantity of selenium intake is necessary for the optimum function of both cellular and hormonal immune processes in humans (51). It also has several health benefits in managing high oxidative stress, human immunodeficiency virus, acquired immunodeficiency syndrome, rheumatoid arthritis, inflammatory or infectious diseases. It is also helpful for people at high risk of cancer especially prostate cancer (52). Selenoproteins such as seleno-methionine and selenocysteine are reported for managing inflammation and inducing immunity (53). The selenoproteins contain the 21 st proteinogenic amino acid, e.g. selenocysteines, represent a group of redox-active proteins.

Selenium regulates both acquired and innate immunity. Selenium induces immunity by enhancing the growth and activity of $\mathrm{T}$ lymphocytes and other immune-competent cells (54). It has also been shown that deficiency of Selenium has a negative impact on immune cells during activation, cell differentiation, and cell proliferation (27). The evidence of immuno-stimulatory effect determined by NK cell activity, $\mathrm{T}$ cell proliferation, innate immune cell functions have been documented $(55,56)$. Consumption of selenium helps in regulating and activating the functions of $\mathrm{B}$ and $\mathrm{T}$ cells leading to adaptive immunity. Selenium levels in-vivo have a positive effect on the proliferation of clusters of differentiating CD $4^{+}$ $\mathrm{T}$ helper cells (57). Lymphocytes with selenium deficiency do not easily proliferate in response to mitogen. Neutrophil chemotaxis also gets affected during selenium deficiency by affecting the macrophages, and leukotrienes B4 synthesis. Selenium deficiency is also known to affect the humoral system e.g. decrease in titers of IgM and IgG in humans. Deficiency of selenium in endothelial cells from asthmatics results in a raise in the expression of adhesion molecules and cause greater linkage of neutrophils (58). The most considerable relation between selenium and the immune system is the effect of the micronutrient on neutrophil function. Neutrophils produce superoxide-derived radicals that help in killing microbes.

\section{Dibenzo- $\alpha$-pyrones}

Oxidative stress causes different stress-induced diseases. Chronic stress is responsible for a significant increase in cortical Superoxide dismutase (SOD), with a concomitant decrease in glutathione peroxidase and catalase activities leading to an increase in lipid peroxidase activity. Both dibenzo- $\alpha$-pyrones and dibenzo- $\alpha$-pyrones chromoproteins significantly mitigate chronic stress-induced perturbations by normalizing activity of SOD and results in reducing the lipid peroxide (59). An immunomodulating antioxidant property of Shilajit extract has been attributed to the combination of dibenzo- $\alpha$-pyrones and fulvic acid (60). Many products that originated from humic substances have been used and tested over decades for antiviral activities as well as antioxidant action, signifying that it has potential applications in the management and prevention of diseases (61). The anti-inflammatory action of potassium humate can be contributed to the suppression of the discharge of inflammatory associated cytokines (62).

\section{Humic substances and Metallo-humates}

Many products originated from humic substances have been used and tested over decades for antiviral activities as well as antioxidant action, signifying that it has latent applications in the management and prevention of diseases (63). The anti-inflammatory activities of potassium humate is able to be contributed to the suppression of the discharge of inflammation-associated cytokines (64).

The principal source of organic components of humic substances is water as well as soil. The humic substances have the capability to form complexes with inorganic and organic compounds and are stable as water-soluble and water-insoluble salts (65). Humic acids have high molecular weights ranging from a hundred to several thousand Daltons (66). Based on their solubility, these natural substances are divided into two important and major categories (i) Fulvic acid, which is soluble in both acid and alkali (ii) Humic acid, which is insoluble in acid

\section{Therapeutic characteristics of Humic substances}

Information on the medicinal use of humic substances has been studied by several researchers. Chinese Materia Medica pharmacological compendium established in the $15^{\text {th }}$ century Ming Dynasty is one of the vital and earliest documentation in this field (62). In China 1978, humic acids and fulvic acids have been used for the treatment of a broad range of diseases and are referred to as "Wujinsan", meaning "Golden Medicine". Chinese drug organization agreed to the humic acid medicines (39). Due to the non-toxicity of humic acid and fulvic acid extract, it is recommended for internal and external use 
(65). Transcript from Ayurvedic medicine strongly denotes to humic dating back over three thousand years (66). Humic and fulvic acids with enriched minerals can be assimilated in the body and helps to stimulate various precise and non-specific biological functions (67). In Natural Traditional Medication System Comprehensive Database, humic substances prevail as a therapeutic agent with a diversity of bioactive potential and then known as dietary supplements as well as cosmetic products (68).

\section{Anti-inflammatory and pro-inflammatory properties of Humic substances}

The anti-inflammatory activity of humic substances has been attributed to the various healing effect of peat therapy (69). Study reveals that sodium humate significantly suppresses the development of various edemas (70). Membrane protective activities of humic acid type substances are evidenced by inhibition in the lipoxygenase pathway of the arachidonic acid cascade, which is an integral part of the cell membrane (69). Fulvic acid can decrease cyclooxygenase 2 and prostaglandin E2 secretion (71). Antiallergic effects of fulvic acid extract from solubilized sludge are shown to decrease histamine and B-hexosaminidase in immunoglobulin-E-sensitized basophil cells and mast cells. Fulvic acid can lower the release of tumour necrosis factors and proinflammatory mediators (72).

\section{Antiviral properties of Humic substances}

The humic substances have been reported to have activity against human RNA viruses. The anti-viral therapies with humic acid as add-on therapy have been used against many human viruses (44). Some of the antiviral activities of humic substances have been discussed below

\section{Herpes simplex virus}

The effect of humic acids on an early stage of Herpes simplex virus replication inhibition has been confirmed by doing animal experiments (73). Shilajit, a well known humic substance has been studied for its antiviral activity against a group of viruses including Herpes simplex type 1 and 2 (74). Phenolic compounds and polyanionic substances of the humic acid have been studied as inhibitors of Herpes simplex virus type 1 replication. The functional group study showed the presence of carboxylic groups in the starting compounds improved the antiviral activity and lessen the cytotoxicity of polymers (75). The antiviral activity of synthetic low-molecular-weight humic acid polymers and naturally occurring humic acids have been studied in-vitro against HSV-1. Humic Acid polymers for example some oxidation products generally suppress virus multiplication with different strength and selectivity $(76,79)$.

\section{Human Immunodeficiency virus}

A polyphenolic compound with a molecular weight of about 1000 Dalton, designated HS-1500, was synthesized by
Synthetic Humate Analogues and derived by the oxidation of hydroquinone. The synthetic analogue HS-1500 has been shown to inhibit the infectivity of HIV particles by interference with virus entry mediated by the V3 loop (78). Further, more studies demonstrated the ability of humic acid to suppress Human immunodeficiency virus type $1(79,80)$. The mechanism of action analysis exposed virus penetration into host cells as the target of the anti-Human Immunodeficiency Virus type-1 activity.

\section{Human respiratory syncytial virus}

Shilajit has been investigated for its antiviral activity against Human respiratory syncytial virus. Partial virus inactivation and intervention with virus attachment mutually contributed to the antiviral activity of Shilajit (81).

\section{Human Cytomegalovirus}

Polycarboxylate (aurintricarboxylic acid) are effective against Human cytomegalovirus replication, without any cytotoxic effect towards humans. These compounds prevent the attachment of viral particles to the cell surface by inhibiting the ionic interactions between the two $(82-83,79)$.

\section{Coxsackie virus}

The humic substances are shown to be effective against Coxsackie $A 9(84,44)$.

\section{Influenza Virus}

Humic acids have been reported to suppress Influenza virus $(85,86)$. Humic substances have proven to be more important as prophylactic candidates rather than therapeutic against viral infections (87).

\section{Vaccinia virus}

Humic acid has an inhibition effect selectively against some of the Vaccinia viruses (88). Reports revealed that humic substances inhibit the early stage of Vaccinia virus replication $(79,84)$.

\section{Potential role of Humic Substance in Covid-19 treatment}

Humic substances including Fulvic acid, Humic acid have been shown to have antiviral activity in vitro. The selenium and DCP have already been shown as Immunomodulatory substances, and boost our immune system which is natural means of protection already existing in our body. The mixtures of these components are being used in traditional medicine for centuries and have shown their value and trust already. The Humic acid substances to be effective against HIV (11) for which no vaccine is available and existing therapeutic agents have severe harmful side effects. These anti-viral activities are versatile and could be used against many other diseases including cancer (89). The use of these substances as a prophylactic measure could provide the needed solution 
to tackle COVID-19 and many more emerging diseases, which may come in future.

In conclusion, humic substances have proven to improve the overall immune system, by forming a set of composite network of cells and proteins that protects humans from germs and infection. Having proven antiviral activities against several human viruses, again make them good candidates that can be used for preventing as well as managing COVID-19.

\section{Abbreviations}

COVID-19: Coronavirus disease 2019

SARS-CoV-2: Severe acute respiratory syndrome Coronavirus-2,

DP: Dibenzo-pyrones

DCPs: dibenzo-pyrones-chromoproteins

Se: Selenium

SOD: Superoxide dismutase

HS: Humic Substances

FA's: Fulvic acids

HA: Humic acids

HSV-1: Herpes simplex virus type 1

HIV: Human immunodeficiency virus

\section{Acknowledgements}

Authors are thankful to Director, CSIR-IIIM for his interest in this work. RSM and DC thank ICMR and UGC respectively for their respective fellowships.

\section{Authors contributions}

DK wrote the introduction of immunomodulatory properties and compiled the table. JKK wrote the antiviral properties. RSM wrote the components \& properties of humic substances and prepared the graphical abstract. DC wrote the nutraceutical properties of humic substances. AC conceptualized, coordinated and corrected the manuscript. All authors read and approved the manuscript.

\section{Sources of funding}

None.

\section{Conflicts of interest}

The authors declare that there are no competing interests.

Received Date: 21-10-20; Revised Date: 26-03-21

Accepted Date: 26-04-21

\section{References}

1. Guo YR, Cao QD, Hong ZS, Tan YY, Chen SD, Jin HJ, Tan KS, Wang DY, Yan $Y$. The origin, transmission and clinical therapies on coronavirus disease 2019 (COVID-19) outbreak-an update on the status. Military Medical Research. 2020 Dec;7(1):1-0.

2. Zhou M, Zhang X, Qu J. Coronavirus disease 2019 (COVID-19): a clinical update. Frontiers of medicine. 2020 Apr;14(2):126-35.

3. Lai CC, Shih TP, Ko WC, Tang HJ, Hsueh PR. Severe acute respiratory syndrome coronavirus 2 (SARS-CoV-2) and coronavirus disease-2019
(COVID-19): The epidemic and the challenges. International journal of antimicrobial agents. 2020 Mar 1;55(3):105924.

4. Zhou F, Yu T, Du R, Fan G, Liu Y, Liu Z, Xiang J, Wang Y, Song B, Gu X, Guan L. Clinical course and risk factors for mortality of adult in patients with COVID-19 in Wuhan, China: a retrospective cohort study. The lancet. 2020 Mar 28;395(10229):1054-62.

5. Bai Y, Yao L, Wei T, Tian F, Jin DY, Chen L, Wang M. Presumed asymptomatic carrier transmission of COVID-19. Jama. 2020 Apr 14;323(14):1406-7.

6. Wilson NM, Norton A, Young FP, Collins DW. Airborne transmission of severe acute respiratory syndrome coronavirus-2 to healthcare workers: a narrative review. Anaesthesia. 2020 Aug;75(8):1086-95.

7. Prajapati S, Kumar N. SARS-CoV-2 pandemic: an opportunity for Indian traditional medicines (AYUSH). Int J Complement Alt Med. 2020;13(3):103-5.

8. Ren JL, Zhang AH, Wang XJ. Traditional Chinese medicine for COVID-19 treatment. Pharmacological research. 2020 May;155:104743.

9. Gangal N, Nagle V, Pawar Y, Dasgupta S. Reconsidering traditional medicinal plants to combat COVID-19. AIJR Preprints. 2020 Apr 15;34:1-6.

10. Ghosal S. Chemistry of shilajit, an immunomodulatory Ayurvedic rasayan. Pure and Applied Chemistry. 1990 Jan 1;62(7):1285-8.

11. Zhernov YV, Konstantinov AI, Zherebker A, Nikolaev E, Orlov A, Savinykh MI, Kornilaeva GV, Karamov EV, Perminova IV. Antiviral activity of natural humic substances and shilajit materials against HIV-1: Relation to structure. Environmental research. 2021 Feb 1;193:110312.

12. Sharma R, Martins N, Kuca K, Chaudhary A, Kabra A, Rao MM, Prajapati PK. Chyawanprash: a traditional Indian bioactive health supplement. Biomolecules. 2019 May;9(5):161.

13. Peschel G, Wildt T. Humic substances of natural and anthropogeneous origin. Water Research. 1988 Jan 1;22(1):105-8.

14. Derrien M, Lee YK, Park JE, Li P, Chen M, Lee SH, Lee SH, Lee JB, Hur J. Spectroscopic and molecular characterization of humic substances (HS) from soils and sediments in a watershed: comparative study of HS chemical fractions and the origins. Environmental Science and Pollution Research. 2017 Jul;24(20):16933-45.

15. Ghosal S. Shilajit in Perspective, first ed. Alpha Science International Limited, Oxford, United Kingdom (2006).

16. Thurman EM, Wershaw RL, Malcolm RL, Pinckney DJ. Molecular size of aquatic humic substances. Organic Geochemistry. 1982 Mar 1;4(1): 27-35.

17. McKnight DM, Andrews ED, Spaulding SA, Aiken GR. Aquatic fulvic acids in algal-rich Antarctic ponds. Limnology and Oceanography. 1994 Dec;39(8):1972-9.

18. Hayes MH, Mylotte R, Swift RS. Humin: its composition and importance in soil organic matter. Advances in agronomy. 2017 Jan 1;143:47-138.

19. Kononova MM, Humus of virgin and cultivated soils. In Soil components 1975 (pp. 475-526). Springer, Berlin, Heidelberg.

20. Sakaki T, Ichihara A, Sakamura S. Isolation of fulvic acid from Cercospora beticola. Agricultural and Biological Chemistry. 1981;45(5):1275-6.

21. Tan KH, Sihanonth P, Todd RL. Formation of humic acid like compounds by the ectomycorrhizal fungus, Pisolithus tinctorius. Soil Science Society of America Journal. 1978 Nov;42(6):906-8.

22. Yuan C, Wang HY, Wu CS, Jiao Y, Li M, Wang YY, Wang SQ, Zhao ZT, Lou HX. Austdiol, fulvic acid and citromycetin derivatives from an endolichenic fungus, Myxotrichum sp. Phytochemistry Letters. 2013 Nov 1;6(4):662-6.

23. Schepetkin IA, Xie G, Jutila MA, Quinn MT. Complement-fixing activity of fulvic acid from Shilajit and other natural sources. Phytotherapy Research: An International Journal Devoted to Pharmacological and Toxicological Evaluation of Natural Product Derivatives. 2009 Mar;23(3):373-84.

24. Weber JH, Wilson SA. The isolation and characterization of fulvic acid and humic acid from river water. Water research. 1975 Dec 1;9(12): 1079-84.

25. Schnitzer M, Skinner SI. Alkali versus acid extraction of soil organic matter. Soil Science. 1968 Jun 1;105(6):392-6. 
26. Hatcher PG, Breger IA, Mattingly MA. Structural characteristics of fulvic acids from continental shelf sediments. Nature. 1980 Jun;285(5766): 560-2.

27. Mishra T, Dhaliwal HS, Singh K, Singh N. Shilajit (Mumie): Current Status of Biochemical, Therapeutic and Clinical Advances. Current Nutrition \& Food Science. 2019 Apr 1;15(2):104-20.

28. Winkler J, Ghosh S. Therapeutic potential of fulvic acid in chronic inflammatory diseases and diabetes. Journal of diabetes research. 2018 Sep $10 ; 2018$.

29. Gonzalez DH, Soukup JM, Madden MC, Hays M, Berntsen J, Paulson SE, Ghio AJ. A fulvic acid-like substance participates in the pro-inflammatory effects of cigarette smoke and wood smoke particles. Chemical research in toxicology. 2020 Mar 19;33(4):999-1009.

30. Arora R, Chawla R, Marwah R, Arora P, Sharma RK, Kaushik V, Goel R, Kaur A, Silambarasan M, Tripathi RP, Bhardwaj JR. Potential of complementary and alternative medicine in preventive management of novel H1N1 flu (Swine flu) pandemic: thwarting potential disasters in the bud. Evidence-Based complementary and alternative medicine. 2010;2011.

31. Petralia R, Nutraceutical beverage [Internet]. US20120213756A1, 2012 [cited 2020 Jun 1]. Available from: https://patents.google.com/patent/US20120213756A1/en

32. Boguta P, Sokołowska Z. Zinc binding to fulvic acids: Assessing the impact of $\mathrm{pH}$, metal concentrations and chemical properties of fulvic acids on the mechanism and stability of formed soluble complexes. Molecules. 2020 Jan;25(6):1297.

33. Saar RA, Weber JH. Fulvic acid: modifier of metal-ion chemistry. Environmental science \& technology. 1982 Sep;16(9):510A-7A.

34. Dastager SG, Deepa CK, Pandey A. Potential plant growth-promoting activity of Serratia nematodiphila NII-0928 on black pepper (Piper nigrum L.). World Journal of Microbiology and Biotechnology. 2011 Feb;27(2):259-65.

35. Cornejo A, Jiménez JM, Caballero L, Melo F, Maccioni RB. Fulvic acid inhibits aggregation and promotes disassembly of tau fibrils associated with Alzheimer's disease. Journal of Alzheimer's disease. 2011 Jan 1;27(1):143-53.

36. Agarwal SP, Anwer MK, Aqil M. Complexation of furosemide with fulvic acid extracted from shilajit: a novel approach. Drug development and industrial pharmacy. 2008 Jan 1;34(5):506-11.

37. Pant K, Gupta A, Gupta P, Ashraf A, Yadav A, Venugopal S. Anti-proliferative and anticancer properties of fulvic acid on hepatic cancer cells. Journal of Clinical and Experimental Hepatology. 2015 Jun 1;5:S2.

38. Cao S. Fulvic Acid Information Asthma and lung infections on the rise in al age groups. Ann Allergy Asthma Immunol. 2000;84:227-33.

39. Yuan S, Application of fulvic acid and its derivatives in the fields of agriculture and medicine $1^{\text {st }}$ ed; 1993

40. Aykac A, Becer E, Okcanoğlu TB, Güvenir M, Süer K, Vatansever S. The cytotoxic effects of humic acid on human breast cancer cells. InMultidisciplinary digital publishing institute proceedings 2018 (Vol. 2, No. 25, p. 1565).

41. Jacob KK, Kj PP, Chandramohanakumar N. Humic substances as a potent biomaterials for therapeutic and drug delivery system-a review. Int. J. App. Pharm. 2019;11(3):1-4.

42. Moulin D, Donzé O, Talabot-Ayer D, Mézin F, Palmer G, Gabay C. Interleukin (IL)-33 induces the release of pro-inflammatory mediators by mast cells. Cytokine. 2007 Dec 1;40(3):216-25.

43. Hafez M, Popov AI, Zelenkov VN, Teplyakova TV, Rashad M. Humic substances as an environmental-friendly organic wastes potentially help as natural anti-virus to inhibit COVID-19. Science Archives. 2020;1(2):53-60.

44. Lu FJ, Tseng SN, Li ML, Shih SR. In vitro anti-influenza virus activity of synthetic humate analogues derived from protocatechuic acid. Archives of virology. 2002 Feb 1;147(2):273-84.

45. Vetvicka V, Baigorri R, Zamarreno AM, Garcia-Mina JM, Yvin JC. Glucan and humic acid: Synergistic effects on the immune system. Journal of medicinal food. 2010 Aug 1;13(4):863-9.
46. Khil'ko SL, Efimova IV, Smirnova OV. Antioxidant properties of humic acids from brown coal. Solid Fuel Chemistry. 2011 Dec;45(6):367-71.

47. Zhao Y, Paderu P, Delmas G, Dolgov E, Lee MH, Senter M, Park S, Leivers S, Perlin DS. Carbohydrate-derived fulvic acid is a highly promising topical agent to enhance healing of wounds infected with drug-resistant pathogens. Journal of Trauma and Acute Care Surgery. 2015 Oct 1;79(4):S121-9.

48. Gandy JJ, Snyman JR, Van Rensburg CE. Randomized, parallel-group, double-blind, controlled study to evaluate the efficacy and safety of carbohydrate-derived fulvic acid in topical treatment of eczema. Clinical, cosmetic and investigational dermatology. 2011;4:145.

49. Ghosal S, Free radicals, oxidative stress and antioxidant defence. Phytomedica1, 1-8 (2000).

50. Barouji SR, Saber A, Torbati M, Fazljou SM, Khosroushahi AY. Health Beneficial Effects of Moomiaii in Traditional Medicine. Galen Medical Journal. 2020 Aug 27;9:1743.

51. McKenzie RC, Rafferty TS, Beckett GJ, Arthur JR. Effects of selenium on immunity and aging. Selenium. 2001:257-72.

52. Ryan-Harshman M, Aldoori W. The relevance of selenium to immunity, cancer, and infectious/inflammatory diseases. Canadian Journal of Dietetic Practice and Research. 2005 Jul;66(2):98-102.

53. Hoffmann PR, Berry MJ. The influence of selenium on immune responses. Molecular nutrition \& food research. 2008 Nov;52(11):1273-80.

54. Ru-duan W, Chang-sen W, Zuo-hua F, Yi L. Investigation on the effect of selenium on T lymphocyte proliferation and its mechanisms. Journal of Tongji Medical University. 1992 Mar;12(1):33-8.

55. Avery JC, Hoffmann PR. Selenium, selenoproteins, and immunity. Nutrients. 2018 Sep;10(9):1203.

56. Kiremidjian-Schumacher L, Roy M, Wishe MI et al, Supplementation with selenium and human immune cell functions. II. Effect on cytotoxic lymphocytes and natural killer cells. Biol. Trace Elem. Res. 1994 41: 115-27.

57. Hoffmann FW, Hashimoto AC, Shafer LA, Dow S, Berry MJ, Hoffmann PR. Dietary selenium modulates activation and differentiation of CD4+ T cells in mice through a mechanism involving cellular free thiols. The Journal of nutrition. 2010 Jun 1;140(6):1155-61.

58. Gill H, Walker G. Selenium, immune function and resistance to viral infections. Nutrition \& dietetics. 2008 Jun;65:S41-7.

59. Knoll J. The Pharmacological Basis of the Therapeutic Effect of (-)-Deprenyl in Age-Related Neurological Diseases. Inhibitors of Monoamine Oxidase B. 1993:145-68.

60. Schepetkin I, Khlebnikov A, Kwon BS. Medical drugs from humus matter: focus on mumie. Drug development research. 2002 Nov;57(3): 140-59.

61. Halliday G, Robinson SR, Shepherd C, Kril J. Alzheimer's disease and inflammation: a review of cellular and therapeutic mechanisms. Clinical and Experimental Pharmacology and Physiology. 2000 Jan 4;27(1-2):1-8.

62. van Rensburg CE. The antiinflammatory properties of humic substances: a mini review. Phytotherapy Research. 2015 Jun;29(6):791-5.

63. Boggs Jr S, Livermore D, Seitz MG, Humic substances in natural waters and their complexation with trace metals and radionuclides: a review. Argonne National Lab., IL (USA); 1985 Jul 1.

64. Perminova IV, Frimmel FH, Kudryavtsev AV, Kulikova NA, Abbt-Braun G, Hesse S, Petrosyan VS. Molecular weight characteristics of humic substances from different environments as determined by size exclusion chromatography and their statistical evaluation. Environmental science \& technology. 2003 Jun 1;37(11):2477-85.

65. Klöcking R, Helbig B. Medical aspects and applications of humic substances. Biopolymers for Medical and Pharmaceutical Applications. WILEY-VCH Verlag GmbH \& C. KGaA. Weinheim. 2005:3-16.

66. Carlos CG, Leonardo G, Ricardo BM. Shilajit: a natural phytocomplex with potential procognitive activity. Int. J. Alzheimer's Dis. 2012;10:1-4.

67. Schnitzer M. Binding of humic substances by soil mineral colloids. Interactions of soil minerals with natural organics and microbes. 1986 Jan 1;17:77-101. 
68. Mirza MA. Future of humic substances as pharmaceutical excipient. Pharma Sci Anal Res J. 2018;1:180004.

69. TAUGNER G. Experimental Animal Studies on a Sodium Huminate-Salicylic Acid Bath. Arzneimittel-Forschung. 1963 Apr;13:329-33.

70. Arif M, Alagawany M, Abd El-Hack ME, Saeed M, Arain MA, Elnesr SS. Humic acid as a feed additive in poultry diets: a review. Iranian journal of veterinary research. 2019;20(3):167.

71. Stepanov N, Senko O, Perminova I, Efremenko E. A new approach to assess the effect of various humic compounds on the metabolic activity of cells participating in methanogenesis. Sustainability. 2019 Jan;11(11):3158.

72. Junek R, Morrow R, Schoenherr JI, Schubert R, Kallmeyer R, Phull S, Klöcking R. Bimodal effect of humic acids on the LPS-induced TNF- $\alpha$ release from differentiated U937 cells. Phytomedicine. 2009 May 1;16(5):470-6.

73. Yamada P, Isoda H, Han JK, Talorete TP, Yamaguchi T, Abe Y. Inhibitory effect of fulvic acid extracted from Canadian sphagnum peat on chemical mediator release by RBL-2H3 and KU812 cells. Bioscience, biotechnology, and biochemistry. 2007 May 23:0704090380.

74. Pant K, Singh B, Thakur N. Shilajit: a humic matter panacea for cancer (2012).

75. Cagno V, Donalisio M, Civra A, Cagliero C, Rubiolo P, Lembo D. In vitro evaluation of the antiviral properties of Shilajit and investigation of its mechanisms of action. Journal of ethnopharmacology. 2015 May 26;166:129-34.

76. Wollina U. Peat: a natural source for dermatocosmetics and dermatotherapeutics. Journal of Cutaneous and Aesthetic Surgery. 2009 Jan;2(1):17.

77. Helbig B, Klöcking R, Wutzler P. Anti-herpes simplex virus type 1 activity of humic acid-like polymers and their o-diphenolic starting compounds. Antiviral Chemistry and Chemotherapy. 1997 Jun;8(3):265-73.

78. Klöcking HP. Influence of natural humic acids and synthetic phenolic polymers on haemostasis. InRecent Developments in Toxicology: Trends, Methods and Problems 1991 (pp. 166-169). Springer, Berlin, Heidelberg.

79. Schneider J, Weis R, Männer C, Kary B, Werner A, Seubert BJ, Riede UN. Inhibition of HIV-1 in cell culture by synthetic humate analogues derived from hydroquinone: mechanism of inhibition. Virology. 1996 Apr 15;218(2):389-95.
80. Schols D, Wutzler P, Klöcking R, Helbig B, De Clercq E. Selective inhibitory activity of polyhydroxycarboxylates derived from phenolic compounds against human immunodeficiency virus replication. Journal of acquired immune deficiency syndromes. 1991 Jan 1;4(7): 677-85.

81. Kornilaeva GV, Siniavin AE, Schultz A, Germann A, Moog C, Von Briesen H, Turgiev AS, Karamov EV. The differential Anti-HIV effect of a new humic substance-derived preparation in diverse cells of the immune system. Acta Naturae 2019;11(2 (41).

82. Thikkurissy S, Pavone A, Rega A, Bae R, Roy M, Wishe HI, Kiremidjian-Schumacher L. Effect of interleukin-2 and selenium on the growth of squamous cell carcinoma cells. Otolaryngology-Head and Neck Surgery. 2001 Feb;124(2):142-9.

83. Baba M, Schols D, Pauwels R, Nakashima H, De Clercq E. Sulfated polysaccharides as potent inhibitors of HIV-induced syncytium formation: a new strategy towards AIDS chemotherapy. Journal of acquired immune deficiency syndromes. 1990 Jan 1;3(5):493-9.

84. De Clercq E, Herdewijn P, Strategies in the design of antiviral drugs. Pharmaceutical Sciences Encyclopedia: Drug Discovery, Development, and Manufacturing 2010 15:1-56.

85. Anesio AM, Hollas C, Granéli W, Laybourn-Parry J. Influence of humic substances on bacterial and viral dynamics in freshwaters. Applied and environmental microbiology. 2004 Aug;70(8):4848-54.

86. Islam KM, Schuhmacher A, Gropp JM. Humic acid substances in animal agriculture. Pakistan Journal of nutrition. 2005 Mar;4(3):126-34.

87. Thiel KD, Klöcking R, Schweizer H, Sprössig M. In vitro studies of the antiviral activity of ammonium humate against herpes simplex virus type 1 and type 2 (author's transl). Zentralblatt fur Bakteriologie, Parasitenkunde, Infektionskrankheiten und Hygiene. Erste Abteilung Originale. Reihe A: Medizinische Mikrobiologie und Parasitologie. 1977 Nov 1;239(3):304-21.

88. Qixin C, Jiqiu L, Hong L, Xinjiang W, Zhan L, Jin Z, Yan L, Haitao W. Experimental study on antiviral mechanism of humic acid. Journal of Chengde Medical College. 1997 Jan 1;14(2):96-8.

89. Hafez M, Popov AI, Zelenkov VN, Teplyakova TV, Rashad M. Humic substances as an environmental-friendly organic wastes potentially help as natural anti-virus to inhibit COVID-19. Science Archives. 2020;1(2):53-60. 